\title{
Defining International Law Librarianship in an Age of Multiplicity, Knowledge, and Open Access to Law
}

\author{
Richard A. Danner
}

\begin{abstract}
Many law librarians are experts in international law and legal research. The concept of 'international law librarianship', however, encompasses something more than a field of study in which a group of experts practise their profession. In the broader sense, the idea suggests a common calling, similar interests, and goals shared by librarians with a range of specialties beyond international law, working in all types of law libraries. What commonalities create and sustain the concept of international law librarianship? This paper suggests that they can be found in: law librarians' common need to respond to the 'multiplicity' of information sources facing twenty-first century legal researchers; the development and nurturing of a shared base of professional knowledge; and a common commitment to work toward ensuring free and open access to legal information globally.
\end{abstract}

\section{Defining International Law Librarianship}

Many law librarians are experts in international law and legal research, each knowledgeable regarding the substance of international law, as well as its primary sources, its literature, its finding tools, and approaches to research. They specialize in international law in the same ways that other subject librarians do in other legal disciplines, as well as in the health sciences, business and many other fields. The concept of 'international law librarianship', however, encompasses something more than a field of study in which a group of experts practise their profession. In the broader sense expressed in the title of this book the idea of international law librarianship suggests a common calling, similar interests, and goals shared by librarians with a range of specialties beyond international law, working in all types of law libraries. ${ }^{1}$ What things are shared by law librarians who involve themselves internationally and may be active in professional organizations such as the International Association of Law Libraries (IALL) and the Law Libraries Section of the International Federation of Library Associations and Institutions (IFLA)?

The mission statement of the International Association of Law Libraries ${ }^{2}$ provides a short list of Association's programmes for 'individuals, libraries, and other organizations

\footnotetext{
* (C) Richard A. Danner 2011. This paper is based in part on an address offered under the title: 'Taming Multiplicity in the Post-Print Era: Law Librarians, Legal Scholarship, and Access to the Law' at Harvard University, 29 April 2010. An earlier version appears as chapter 1 of Danner, R. and Winterton, J. (eds.) (2011), IALL International Handbook of Legal Information Management (Farnham, England: Ashgate). Thanks to John Palfrey and Michelle Pearse for the opportunity to speak at Harvard and to Amanda Barratt for her helpful comments on earlier drafts.

${ }^{1}$ See Danner, Estes and Meadows (2009) for descriptions of the roles of various types of law libraries.

${ }^{2}$ http://www.iall.org/about.html, accessed 30 June 2010.
} 
concerned with the dissemination of legal information': IALL promotes their work, provides educational programming, offers financial support for new legal information professionals (especially from developing nations), provides forums for sharing professional information and knowledge, fosters networking and mentoring, supports and encourages national and international legal information policies, and promotes free access to legal information worldwide. The IFLA Law Libraries Section mission statement ${ }^{3}$ is similar to that of the IALL, but also speaks specifically of its interest in fostering the profession and developing professional standards and practices. While suggestive, neither statement provides a satisfactory definition of international law librarianship.

In writing about foreign, international and comparative law collection building, Holger Knudsen makes a seemingly obvious, but actually rather subtle, point when he writes 'Law is a genuinely national affair and this makes it very different from other fields of knowledge with the exceptions perhaps of some rather limited fields of interest like foreign literature, foreign history and ethnology' (Knudsen 2011, 248). Law of course is not a 'rather limited field of interest', but a subject of vital importance to many. The differences among jurisdictions and legal systems that Knudsen notes create obstacles for those seeking to be knowledgeable about the law either to represent the interests of clients or for purposes of scholarship. Knudsen goes on to point out that the obstacles extend beyond substance to the forms and formats of the published sources of law:

Lawyers and law librarians dealing with foreign law for the first time are often surprised or even shocked when they notice how much other formats differ from the system they know. While the appearance, layout and handling of legal monographs and periodicals generally do not pose problems of format, official journals, law collections, court decisions, and finding tools do, and to quite an extent. Even experienced reference librarians who have not worked with foreign materials for a while must try to get acquainted with them anew each time they use them. It is simply impossible to memorise all the different formats (Knudsen 2011, 249).

The differences among nations in substantive law, legal systems and the forms, formats and structures of legal information affect not only the work of students, lawyers, legal scholars, and law librarians, but also the efforts of anyone seeking to define or apply the concept of international law librarianship. ${ }^{4}$ In light of these significant differences it is necessary to identify and consider what things are shared by law librarians world-wide. What commonalities create and sustain the concept of international law librarianship? This chapter suggests that they can be found in: law librarians' common need to respond to the 'multiplicity' of information sources facing twenty-first century legal researchers; the development and nurturing of a shared base of professional knowledge; and a joint commitment to work toward ensuring free and open access to legal information globally.

\section{An American Story}

At the International Association of Law Libraries' twenty-first annual course on

\footnotetext{
${ }^{3}$ http://www.ifla.org/en/law-libraries, accessed 1 August 2010.

${ }^{4}$ For an application of the concept, see Garavaglia 2011, 350-351 ('Is there a need to develop competencies for international law librarianship on a global scale?')
} 
International Law Librarianship in 2002, I was privileged to share a podium with Morris L. Cohen, who had served as the Law Librarian at Harvard University from 1971-81 before moving to the Yale Law School, where he retired in 1991. Cohen is one of the giants of American law librarianship: one of his major accomplishments is his Bibliography of Early American Law, begun in 1984 and published in six volumes in1998 (Cohen 1998).

Cohen's remit for our presentation to an audience of international law librarians was to provide an historical overview of American law publishing; mine was to discuss 'Contemporary and Future Directions in American Legal Research', a topic I developed around the legal scholar Karl Llewellyn's concept of the 'threat of the available':

[T] he almost inevitable tendency in any ... any study, first to turn to the most available material and to study that--to study it exclusively; [then], having once begun the study of the available, to lose all perspective and come shortly to mistake the merely available, the easily seen, for all there is to see (Llewellyn 1931, 95-96, quoted in Danner 2003, 182).

In his own talk, using an array of slides and images, Cohen guided his listeners through several hundred years of legal publishing in England and America, concluding with a description of how:

in the 1880s, American law publishers produced a series of bibliographic innovations which were to shape legal research for at least the next hundred years. ... services designed to serve bibliographic needs that had long existed in the common law system: supplementation and updating of primary sources; subject access to chronologically published material; authority verification of primary sources; and access to descriptive and interpretive secondary sources. (Cohen 2003, 175).

Most importantly, as Cohen put it: 'They also helped to integrate and cross-reference [what he called] the multiplicity of legal sources for the convenience of researchers' (Cohen 2003, 175, emphasis added).

He continued for a bit, but for the most part, Cohen had reached the end of his story: the late nineteenth century innovations in legal publishing he described remained at the core of the US legal information system until the last quarter of the twentieth century, when the first commercial legal research databases Lexis and Westlaw were introduced, followed by the availability of increasing amounts of legal information via the Internet. But, at our programme, that was my story to tell.

Cohen's use of the phrase 'multiplicity of legal sources' to describe the late nineteenth century legal information environment linked back directly to how American lawyers of the time had described what they saw as the overwhelming number of published sources - mostly cases - with which they needed to deal. Not subject to Llewellyn's 'threat of the available', many were disparagingly referred to as 'case lawyers': lawyers who believed that their job was to find every case possibly on point for the issue with which they were confronted (Davis 1918). The ever-growing number of published opinions swamped them, but their desire to locate every case of possible relevance helped sustain the market for more and more cases to be published. 
It was neither new nor unusual for lawyers to complain about 'too much law'. Common law lawyers working in systems relying on the precedents found in judicial opinions had complained about having to deal with too many opinions, too much law, at least as far back as the time of Francis Bacon in the early seventeenth century. ${ }^{5}$ Concerns about too many law books are limited neither to common law legal systems nor to the post-Gutenberg age. ${ }^{6}$

In the USA, there were fewer than 20 volumes of American case law in 1810 (Hicks 1923, 111). Still, the authors of the first two major commentaries on American law, Joseph Story and John Kent, each expressed concern over the amount of law with which lawyers had to deal. In a 1921 address, Story warned of 'the fearful calamity, which threatens us, of being buried alive, not in the catacombs, but in the labyrinths of the law' (Story 1829, 31). In the first volume of his Commentaries on American Law, Kent noted the 'consequence[s] of the number of books which beset and encumber the path of the student', and ' $[\mathrm{t}] \mathrm{he}$ evils resulting from indigestible heaps of laws and authorities ... [which] destroy the certainty of the law, and promote litigation, delay, and subtility [sic]'(Kent 1826-30, I:441-2). In 1840, a comment in The American Jurist feared that 'there are many young lawyers who find themselves in the dilemma of ... [Erasmus], called upon to select between law books and clothes' (Review of Peters's Digest 1840, 244). At the time there were probably about 600 volumes of American reports for lawyers to contend with (Hicks, 1923, 111).

After the American Civil War, the body of US law grew steadily, seemingly exponentially, spurred by geographic expansion, economic growth, increases in the numbers of courts and judges issuing opinions, and the publication of appellate court opinions not only in the official reports issued by the courts but in unofficial commercially-published reporters. Throughout the last quarter of the nineteenth century, the annual meetings of the American Bar Association rang with calls to reduce the 'multiplicity of decisions' being issued by the courts and published in frequently duplicative series of reports. In 1885, it was noted that the decisions of 11 states were available in two or three commercial versions in addition to the official reports published by the states ('New Reporters', 932).

From that period on, American lawyers, law students, scholars, and everyone working with the law have been awash in a constantly rising sea of legal information, staying afloat only because of the tools created by legal publishers to organize and index the law. The West Publishing Company and other US publishers thrived because of the powerful tools they provided to lawyers forced to contend with the ever-growing multiplicity of sources of law. As Morris Cohen put it: '[T] he materials of our law seem to be marked by an accelerating birth rate, an almost non-existent mortality rate, and a serious resistance

\footnotetext{
${ }^{5}$ In 'A Proposition to His Majesty ... Touching the Compiling, and Amendment of the Law', Bacon recommended eliminating from the law reports cases that were 'clearly no law', 'cases merely of iteration and repetition', cases 'judged to the contrary', and cases containing 'idle queries'. In addition, 'cases reported with too great prolixity would be drawn into a more compendious report' (Bacon, c.1616, 68, 69). ${ }^{6}$ Michael Hoeflich has pointed out that the problems of dealing with large amounts of legal sources extend back 2,000 years and not only to common law systems, but he also notes particularly the growth in amount after the mid- fifteenth century prompted not only by the development of printing with moveable type, but the rise of nation-states, which required lawyers to deal with Roman law, canon law, and the law of their states (Hoeflich 2002, 92-3).
} 
to contraception on the part of both judges and legislators' (Cohen 1969, 183).

Yet, throughout much of the twentieth century, despite the amount of law being produced, law librarians could feel that they had some control over the literature of the law. Despite its continuing growth - there were an estimated 3 million reported decisions in the US when the first commercial electronic legal databases were introduced in 1975 $\left(\right.$ Jacobstein and Mersky 1977, 7) ${ }^{7}$ - the literature of the law was organized and findable.

The law books were in the law libraries and the systems of legal research were wellestablished. American law librarians knew and understood how the digest system worked, knew how to use loose-leaf services and pocket parts to update volumes, understood the mysteries of the Shepard's citation-checking system and the arcane rules of legal citation, which the Harvard Law Review first foisted on legal writers in $1926 .{ }^{8}$ They had little reason to question the value of their work or whether there might be other ways to do it. Despite their eventual impacts, the introduction of the Lexis and Westlaw legal research systems in the mid-1970s did not immediately transform the law librarian's work. As Bob Berring has pointed out, these were at first conservative innovations, which 'aped the functions of the old [print] system' (Berring 2000, 1996). The so-called 'computerassisted legal research systems' were designed to attract end-user lawyers, so connections to the familiar books of the law were important. Westlaw itself was originally marketed as an index to the cases published in West books.

By the 1980s, legal information in digital formats had become widely accessible to American law students and professors, lawyers, judges, and other legal professionals via Lexis, Westlaw and CD-ROMs. After the mid-1990s, when the availability of WorldWide-Web and graphical browsers began to make it possible for anyone to 'travel through the online world along paths of whim and intuition' (Wolfe 1994, 116), not only was legal information increasingly available to wider audiences through the Internet but a new world of non-legal sources became readily accessible and was used by legal professionals. Fred Schauer and Virginia Wise found that, with ready electronic access to materials outside the coverage of Lexis, Westlaw and the law library, US courts were more and more frequently citing authorities other than cases and statutes in their decisions (Schauer and Wise, 2000).

Just as 100 years earlier, when lawyers found themselves faced with a 'multiplicity of decisions', in the late twentieth century lawyers, law librarians and others working with legal information were faced with a new 'multiplicity of sources,' this time encompassing not only growing amounts of judge-made and statutory law, but also material which fell outside the controlled apparatus of the familiar systems for finding the printed law. Bob Berring had compared the role of West's tools in providing and maintaining a shape to the common law at the end of the nineteenth century, to that played by Blackstone's Commentaries in the eighteenth century. At the end of the twentieth century, he was calling for a new Blackstone, 'someone......who can re-conceptualize the structure of legal information' (Berring, 2000a, 315).

\footnotetext{
${ }^{7}$ In 1975, 44,000 new cases were published each year (Jacobstein and Mersky 1977, 17); in 2009, there were over 7,000,000 published reports and 200,000 added each year (Barkan, Mersky and Dunn 2009, 32). ${ }^{8}$ http://www.legalbluebook.com/Public/Introduction.aspx, accessed 17 August 2010.
} 


\section{The Twenty-First Century Legal Information Environment}

In his 2008 book, The End of Lawyers, Richard Susskind wrote that 'the really exciting developments that will penetrate to the very heart of legal service' are yet to come. Susskind emphasizes not only the idea that 'what lawyers have enjoyed so far is little more than improved plumbing', but also that (quoting William Gibson) 'the future has already arrived. It is just not evenly distributed yet' (Susskind 2008, 21-2). This is no doubt true, not only among the world's legal jurisdictions, but within them. However, for law librarians, perhaps more than for other segments of the legal profession, the future has both arrived and is widely distributed. Since the late twentieth century, law librarians in all parts of the world and in all areas of specialization were forced to consider the impacts of information technologies on their libraries and their profession, and to think harder about what they had in common with other information professionals. Betty Haugen has noted three key characteristics of legal information in the present era:

- Although digitalization has made the flow of information across national borders faster and easier, it has increased the inequality of access... .

- The distribution of intellectual content is increasingly in the hands of private industrial corporations... . Most of the legal materials are generated in public or academic institutions. As commercial vendors have taken over distribution, access has become restricted for these same public and academic institutions... .

- The cost of maintaining access is becoming prohibitive even for relatively affluent law libraries in the Northern Hemisphere, let alone for their poorer Southern counterparts. (Haugen 2005, 473)

The United States experience of course cannot be taken as representative of other jurisdictions, either in the history of the forms in which is legal information have been published or in the ways that American legal scholars, law students, and lawyers access and use legal information in the early twenty-first century. Because of its size, common law heritage, multiple jurisdictions, multi-level appellate court systems, and long reliance on competitive commercial publishers as well as the government to publish and distribute the law, America is in many ways unique. In a globalized world, however, changes in the legal information environment, recent and still to come, are likely to impact the work of all lawyers and law librarians no matter where they are, no matter where the changes originate. Increasing amounts of legal information are available (or potentially available since they are created in digital formats) in all jurisdictions; the definition of what is considered to be 'legal information' is expanding; and the Internet is affecting the practice of law, legal education and legal scholarship.

\section{What Librarians Do}

In 1996, a report of the American Association of Law Libraries (AALL) Special Committee on the Renaissance of Law Librarianship in the Information Age analyzed the churning information environment of the time and defined the mission of law librarianship in terms of 'serving the information needs of the legal profession and the legal information needs of the public', noting that the things law librarians do, the things traditionally identified with librarianship: 'acquiring, collecting, organizing, retrieving, and disseminating legal and related information are only subsets of that basic mission' 
(Toward a Renaissance 1997, 8-9, emphasis added).

At the time when the report was issued, the notion that providing services to the users of legal information should be the basis for law librarianship's claims to professional status seemed uncontroversial. More recently, however, James Donovan, a librarian at the University of Georgia Law Library, challenged the idea, urging law librarians not to forget the importance of their traditional role in collection development as they face the new challenges of the twenty-first century. From Donovan's perspective, the library's traditional roles: 'acquiring, collecting, organizing, retrieving, and disseminating ... information [create] independent obligations toward collection development and the organization and preservation of knowledge and information in all its forms,' which 'extend beyond immediate patron services'. For Donovan, 'It is commitment to these higher ends - ends that are not reducible to patron services or satisfactions alone - that elevates librarianship to the status of a profession' (Donovan 2008, 123-4).

Echoing Ranganathan's Laws of Library Science (Ranganathan 1931), Donovan set out 'the librarian's core functions [as] to acquire the right books, to make them accessible, and to assure their continued availability', and stating that collection development is 'perhaps the cardinal function of the library' (Donovan 2008, 124). Harvard University's associate librarian for collection development Don Hazen has noted that librarians have traditionally assembled materials that are not "not a random bunch of stuff, but can actually support and sustain some kind of meaningful inquiry'. Hazen goes on to say, however, that: 'Internet search explodes the notion of a curated collection in which the quality of the sources has been assured.... The notion of collection that's implicit in 'the universe is at my fingertips' is diametrically opposed, really, to the notion of collection as 'consciously curated and controlled artifact' (quoted in Shaw 2010, 37; emphasis in original). As Nicholas Carr puts it: 'We no longer have the patience to await time's slow and scrupulous winnowing. Inundated at every moment by information of immediate interest, we have little choice but to resort to automated filters, which grant their privilege, instantaneously, to the new and the popular' (Carr 2010, 171).

How much collection development work will there be for librarians in an environment where information of all types is published digitally, sought in digital formats by researchers, needed immediately, and typically accessed through networked sources located beyond the libraries walls? For librarians, as Hazen notes, 'Internet search engines fundamentally challenge our understanding of where we add value to this process' (quoted in Shaw 2010, 37).

Harvard Law Librarian John Palfrey has written that 'Libraries must perceive our primary function as serving communities rather than building collections' (Palfrey 2010, 185). In his 2010 keynote address to the American Association of Law Libraries, library educator R. David Lankes followed suit, stating that 'The mission of librarians is to improve society through facilitating knowledge creation in their communities' Lankes, 2010). How best do we do this? In law, certainly, the reason for librarians' efforts to select, organize, and preserve legal information has been to enable those who need that information both to find it and to use it effectively; it has not been to create collections for their own sake. Still, to argue that service to communities is the basis for the profession of law librarianship in the digital environment, it is necessary to determine 
what services users of legal information will require and whether librarians are likely to be positioned to provide them. ${ }^{9}$

\section{Libraries and Librarians in the Twenty-First Century}

Most prognosticators on the future of libraries and librarians see little reason for librarians to be complacent regarding their future roles in a changing information environment over which they have little control. Many criticize the profession not only for realizing too late that the Internet has dramatically diminished the value of local collections and services (see for instance Ross and Sennyey 2008, 146), but for failing to recognize that digital information is not the same as print - despite the attraction of pretending that it is (Joint 2006, 15).

In the USA, there is plenty of evidence that direct electronic access to information to the stuff of scholarship - has affected researchers' use of the library and perceptions of its role. A series of reports from Ithaka $S+R^{10}$ documents a continuing and growing disconnection between faculty and librarian perceptions regarding the importance of the several roles played by the library and librarians in support of research and scholarship (see Schonfeld and Housewright 2010). Based on surveys conducted in 2000, 2003, 2006, and 2009, the Ithaka studies suggest that, although faculty respondents continue to value highly the library's roles, particularly as purchaser of shared resources and archive, they (with some variations by discipline) view the library as playing an increasingly less important role in providing gateways to information they need for their research. The results indicate that faculty perceptions of the library's importance are based less on their need for librarians to help them locate and evaluate information than on the library's purchase and preservation of collections, which in print formats are becoming less important for research in many fields. Humanities scholars continue to place more importance on the library's gateway role than researchers in the hard sciences, with social scientists (including legal scholars) between the two, but the decline 'has been steady and consistent over the last ten years, holding across disciplinary groupings' (Schonfeld and Housewright 2010, 8-14, 12).

The most recent Ithaka report did not present information about librarians' attitudes, but the report from 2008 suggested that faculty perceptions of the decreasing importance of the library's role as a gateway to information stood 'in stark contrast' to librarians' own sense of the importance of that role. Over ninety percent of librarians surveyed in 2006 saw the gateway role as 'very important' and almost as many expected it to remain so (Housewright and Schonfeld, 2008, 6). Other research, however, indicates that 'classroom faculty often rate librarians as one of the least likely sources to which they would turn when seeking information' (Kotter 1999, 296).

In a 2010 article in Educause Review Richard Katz explains this in terms of the new 'information and scholarly communication environments that are emerging in the Digital Age [which] are empowering scholars and are enriching scholarship in palpable ways' by providing:

\footnotetext{
${ }^{9}$ See Windsor and Friedman (2010) for a suggestion that in the law firm environment, the idea of 'library as service' may be best effected through outsourcing.

${ }^{10} \mathrm{http}: / /$ www.ithaka.org/ithaka-s-r, accessed 21 August 2010.
} 
- rapid and low-cost connection with other scholars;

- tools that promote the capacity for multi-tasking, multi-processing, and otherwise dividing our attention; and

- access to an abundance of easily discovered recorded knowledge (Katz, R. $2010,48)$.

For Katz, the Internet's greatest boon to scholarship is direct access to research information, because it frees scholars from what he calls the 'busy-ness' of scholarship:

the tyranny and expense of finding, acquiring, sorting, verifying, annotating, collating, validating, and classifying information. Before the Internet, ... tasks of looking endlessly through search aids, waiting for the machinery of interlibrary exchanges of materials to issue forth, ... [earning] the right to delight in finally gaining access to rolls of nearly unreadable microfilm (Katz, R. 2010, 48).

Now, says Katz: 'The discovery of rich content is mediated and simplified by search engines .... The results ... can be a personal scholarly library that is richly annotated and fully searchable using computer-based text or data analysis'; this for Katz is 'the liberating impact of digital technologies on the scholarship of discovery' (Katz, 2010, 49). ${ }^{11}$ For librarians, of course, the suggestion scholars might consider library-centred research to be a matter of 'busy-ness' could be read more starkly as 'perhaps...they really don't need us'.

\section{Law Librarians and Law Libraries in the Twenty-First Century}

In much of the world, law professors and practising attorneys are well-accustomed to the rich full-text resources of legal information databases, and to desktop delivery of new scholarship through electronic working papers services like the Social Science Research Network (SSRN) or the vast journal repositories provided by HeinOnline, other aggregators, and journal publishers. As in other fields of study, the Internet has transformed the research process in law by bringing a wealth of published and unpublished information to the desktop, and by allowing scholars and attorneys to move easily and seamlessly from source to source, paper to paper, article to article, conversation to conversation (see Susskind 2008, 276). As Nicholas Carr says: 'the Internet is a machine designed for the efficient, automated collection, transmission, and manipulation of information....' (Carr, 2010, 150).

No doubt, this 'important lesson' from the 2008 Ithaka report applies to law, as it does to other fields:

[T]he library is in many ways falling off the radar screens of faculty. Although scholars report general respect for libraries and librarians ... [r] longer use the library as a gateway to information, and no longer feel a significant dependence on the library in their research process. ... In short,

\footnotetext{
${ }^{11}$ Some research suggests, however, that ready electronic access to the scholarly journal literature has led researchers to find and read fewer articles than before, and to cite more recent articles, leading online researchers both to more easily find 'prevailing opinion' and to follow it. 'This research intimates that one of the chief values of print library research is poor indexing' (Evans 2008, 398).
} 
although librarians may still be providing significant value to their constituency, the value of their brand is decreasing (Housewright and Schonfeld 2008, 30).

At a 2008 colloquium on 'The Law Librarian's Role in the Scholarly Enterprise', noted scholar Stanley Katz said that: 'digital scholarship is almost by definition collaborative.... Digital scholars are ... co-makers and end-makers rather than end-users of technology and information in this new environment. This is a challenge to the humanities tradition of lonely scholarship, and this has also been the tradition that has been dominant in law schools' (Katz, S. 2010, 364). Where do librarians fit into this new collaborative scholarly environment?

In universities, scholars know little about what librarians do; they know about the library and its collections of resources, and the services it offers in support of their teaching and research. Their views of librarians are strongly coloured by what they observe librarians doing: usually reference librarians practising their profession, offering assistance to those seeking information. They do not see librarians doing the things that they and other faculty do; they do not see them doing research to advance knowledge in their field or teaching what they know to others. As Barbara Kellogg puts it: "the very "practice" of librarianship makes it the application of knowledge and not the advancement of knowledge' (Kellogg 1987, 605). One study suggests that '[F]aculty see librarians as a resource (in some cases, a last resort) for gaining access to materials, not as experts who may play a central role in the preparation and execution of a research project.' (Christiansen, Stombler and Thaxton 2004, 119).

In part, of course, the disconnection is based in the faculty's view that librarians' work is service-oriented, while their own work 'focus[es] on the production and dissemination of knowledge'. Because they usually encounter librarians providing reference services, they have little sense of other things that librarians do: 'research projects and publishing, creating new systems and techniques for searches, the development of collections, the development of courses, and so forth' (Christiansen, Stombler and Thaxton 2004, 119, 148-149). Based on what they see, they have little reason to think of librarians in roles beyond providing services in support of their own research and teaching. Is emphasizing service then no better for librarians' professional status than emphasizing collection development?

Law librarians and other librarians often argue that greater collaboration with faculty - becoming partners in their research - is essential to the future of the profession. However, collaboration has proven to be something much easier for librarians to discuss among themselves, to propose, than to put into practice (Christiansen, Stombler and Thaxton 2004, 117). It is rarely something scholars raise among themselves or discuss with librarians. (Most studies on the subject are conducted by librarians; how better to collaborate with librarians is not a topic to generate much interest in other disciplines. ${ }^{12}$ ) Research on faculty / librarian relations consistently shows that the barriers to collaboration are significant.

\footnotetext{
${ }^{12}$ One review of the literature on librarian-faculty relations notes that most studies on the subject are in the literature of librarianship; there has been little interest in the social sciences (see for instance Christiansen, Stombler and Thaxton 2004). For a comprehensive review of the literature on librarian-faculty relations, see Kotter (1999).
} 
To work effectively with faculty, law librarians must do more than become familiar with a professor's current research interests. To be creative in finding new ways to support faculty research, they need also to be knowledgeable about how scholars work, ${ }^{13}$ to understand the cultural differences between librarians and the creators of scholarship, and how the Internet has impacted relationships between the two groups. The studies indicate that, despite the potential for interaction and collaboration that librarians see in the academic workplace, 'there is an asymmetrical disconnection ... between librarians and faculty'. While the culture of libraries encourages 'sharing, cooperation, and collaboration', faculty are more likely 'to value solitary work highly and to maintain exclusive control over teaching and research projects' (Christiansen, Stombler and Thaxton 2004, 117, 118).

Clearly, however, increased interest in collaborative and interdisciplinary scholarship is altering the traditional image of the solitary scholar in law just as in other fields of study. When they think of collaboration, however, law professors and others think in terms of working with scholars in fields beyond their own (Christiansen, Stombler and Thaxton 2004, 118). They are not disposed to think of librarians as fellow faculty members, nor to consider librarianship a field of study or discipline like their own or those of faculty in other academic departments. Librarians are not seen as having the kinds of expertise needed to be thought of as likely collaborators. Collaborators become co-authors of published research papers; librarians are acknowledged for their contributions in footnotes.

It is well-established that the concept of academic discipline is crucial to the way that faculty members think about matters of status and relationships within the university (see for instance Kellogg 1987, 602). When they think about research, faculty members have in mind a fundamental process aimed at advancing the body of knowledge within their discipline. Law professors understand the research process in their own field and know that something similar takes place in other disciplines. Because they understand that interdisciplinary research may provide powerful new insights into their own research interests, they increasingly seek collaborative relationships with scholars from other disciplines, their peers in the scholarly enterprise. What potential for scholarly collaboration does the law librarian bring to the table from an interdisciplinary perspective?

\section{Professional Knowledge: The Study of Legal Information}

From its origins in trade and practice, in many countries law has become a recognized discipline in the academy, a field of study like many others. In addition, the standard subjects taught in law school courses, as well as areas of specialized legal practice or of scholarly research are themselves often referred to as 'legal disciplines' ${ }^{14}$ Under this

\footnotetext{
${ }^{13}$ For perspectives on the cultures of today's law faculties, see Lewis (2002) 90-92; Shilt (2007), 195-7; Boon and Webb (2010), 79-88; Davidson (2010). See also the discussion 'On Disciplinary Cultures' in Lamont (2009), 53-106.

${ }^{14}$ For lists of legal disciplines, see the subject headings for University of Washington Marian Gould Gallagher Law Library Current Index to Legal Periodicals (http://lib.law.washington.edu/cilp/revsub.html, accessed 30 September 2009) or the 'Browse by Discipline' page for the NELLCO Legal Repository, (http://law.bepress.com/repository/subject_areas.html, accessed 29 September 2009).
} 
rubric, constitutional law is a discipline, as are intellectual property, contracts, evidence and other areas of specialized study, research, and practice. Do law librarians have a field of study, an area in which there is a body of knowledge to be learned, developed, nourished and taught? ${ }^{15}$

Law librarians have argued that legal research provides the substantive discipline for their field. Yet, not only law librarians, but law professors, attorneys, paralegals, and other legal professionals engage in legal research, write about it, and teach it. ${ }^{16}$ Moreover legal research is not a field generally thought to be on a par with other legal specialties. In 1975, at about the time that Lexis and Westlaw were being introduced to US lawyers, Peter Nycum began a paper titled: 'Legal Research - The Unrecognized Legal Discipline' with the observation that 'legal research is not unrecognized as existing, ... rather [it] is unrecognized as being of any consequence to the profession' (Nycum 1975, 82).

Though dated in many respects, Nycum's paper remains a valuable review of reasons why the importance of legal research is not recognized either by legal scholars or by practising lawyers. Nycum found hope, however, in the newly established field of information science, referencing an article by noted library scholar Jesse Shera, who had recently argued that information science would provide a 'theoretical base for the practice of librarianship' (Shera 1968, 64). Nycum called for the blending of 'the two disciplines, law and information [to] creat[e] a unified specialized discipline of legal information science'. Sketching out what would be needed to develop the new discipline, Nycum stated that 'leadership for the [new field] will have to come from either the law schools, the practising bar or zealous individuals'. Noticeably absent from his list were law librarians, who Nycum believed would not take leadership in the effort in part because the number of law librarians "who can contribute to the intellectual and theoretical base of legal information science is very small' (Nycum 1975, 98).

A new discipline of legal information science did not develop along the lines suggested by Nycum. By the mid-1980s, however, growing academic interest in the impacts of information technologies on the law began to foster a new literature on the role of legal information. In the USA, M. Ethan Katsh introduced to legal scholarship the idea that the forms through which information is communicated can be as influential on values and institutions as its content (Katsh 1984). In the same year, Jon Bing of the Norwegian Research Center for Computers and Law, published his edited work: Handbook of Legal Information Retrieval. Bing's Handbook was a major contribution which updated an earlier volume (Bing and Harvold 1997) and included an international survey of legal information retrieval systems (Bing 1984, 247-497).

The publication of these works and other scholarship in the mid-1980s signalled an evolution in the literature of law and information technology away from its original focus on the technical aspects of legal information systems to consideration of the ways in

\footnotetext{
${ }^{15}$ In 1992, library educator Sydney Pierce questioned whether librarianship itself is a field characterized either by seminal thinkers or by 'a common body of knowledge shaping the intellectual traditions of the field' (Pierce 1992, 641).

${ }^{16}$ In the USA, legal writing teachers, whose status in the academy is similar to that of law librarians, are probably unlikely to cede a legal research discipline to law librarians (especially if it were recognized as a legitimate field of study).
} 
which the formats of both print and digital legal information and the systems that deliver the information affect the practice of law and legal scholarship. In the USA, Bob Berring and other law librarians, law professors and scholars in the information sciences, developed a rich literature on the impacts of legal information (Danner 2008). A conference in 2006 celebrating the contributions of Berring and other writers demonstrated that this literature remains vital and wide-ranging, and is recognized by legal scholars in other specialties (Danner and Houdek 2008).

The scholarly literature on the role of legal information is both interdisciplinary ${ }^{17}$ and international in scope. In Europe, Jon Bing has continued to make significant contributions. In the United Kingdom, Colin Tapper's work on online information systems has been noted for its international impact (Treitel 2003, viii) and for bringing academic approaches to the field (Bing 2003, 148). Richard Susskind's several books on the impacts of information technologies on the law and the legal profession include thoughtful and provocative commentary on topics of legal information and access to the law (see for instance Susskind 2008). Peter Wahlgren's book: The Quest for Law: Law Libraries and Legal Information Management of the Future appeared in 1999. The BIALL Handbook of Legal Information Management was published in 2006 (Worley 2006); Abdul Paliwala's A History of Legal Informatics in 2010. In Australia, the works of Graham Greenleaf and colleagues have shaped the international development of open access to the law (see for instance Greenleaf 2004; Greenleaf, 2010).

Throughout its history, the International Journal of Legal Information (IJLI) has published notable contributions on topics of legal information and the broader impacts of online legal information on legal research and the law by librarians and law professors from throughout the world. Papers presented at the annual courses of the International Association of Law Libraries have been regularly published in the IJLI and occasionally in separate volumes of proceedings. Works on legal information frequently appear in other journals of law and librarianship as well.

Today, an SSRN e-journal makes available new scholarship and working papers on the topic of Legal Information \& Technology alongside the other legal disciplines listed by SSRN. ${ }^{18}$ Many of those papers are written by law librarians, belying Nycum's doubts that the profession would make meaningful contributions to the development of its own knowledge base. ${ }^{19}$ New scholarship by law librarians is presented, just as for other legal disciplines, at conferences of national law library associations, associations of legal educators, ${ }^{20}$ at the annual courses of the International Association of Law libraries, at

\footnotetext{
${ }^{17}$ It is important that the subject of research interest to law librarians also be of interest to scholars in law and other disciplines. When Sydney Pierce's article questioning the knowledge base of librarianship was published in 1992, a sidebar presented prominent librarians' lists of those whose scholarship had influenced the field. The lists included librarians but also a range of scholars from other disciplines. The short article noted that 'all professions are derivative' (T.G. 1992, 643).

${ }^{18} \mathrm{http}: / /$ www.ssrn.com/lsn/index.html, accessed 2 August 2010.

${ }^{19}$ In the USA one reason for this is presumably the growth since 1975 in the number of law librarians with advanced degrees in both law and library or information science. Data compiled by the American Association of Law Libraries indicate that 30.1 percent of academic law librarians in the USA hold both law and library science degrees (AALL Biennial Salary Survey 2009, 11).

${ }^{20}$ See, for example, 'Law Librarian as Scholar: Legal Authority and Research in an Age of Accessibility', in Association of American Law Schools 2010 Annual Meeting Program: Transformative Law 43 (2009).
} 
programmes of the IFLA Law Libraries Section, and elsewhere. In addition to the International Journal of Legal Information there are a number of established national journals publishing scholarship on topics of legal information. ${ }^{21}$ Law library associations also offer research agendas listing topics of importance for research. ${ }^{22}$

Perhaps the discipline Peter Nycum called for in the 1970s is emerging. Whether it will be recognized by scholars in other legal disciplines and become of interest for collaborative projects remains to be seen. However, the scholarship produced throughout the world by law librarians and others on the subject of legal information has certainly created a knowledge base for law librarianship that answers Sydney Pierce's concerns regarding the existence of a 'common body of knowledge', and creates one of the commonalities of international law librarianship. ${ }^{23}$

\section{Access to the Law}

Library historians point out that in the early twentieth century, librarians not only acted as guardians of information resources, but were also the primary creators of the indexes and other finding tools that researchers used to locate the resources needed for their work. Stuart Sutton suggests that this role ended after the first world war, when 'the profession went... to sleep and its practitioners became mere tool-users...[losing] much of the power to enable the profession' (Sutton 1995, 9). Kenneth Carpenter has argued that, as universities came increasingly to focus on the creation of knowledge rather than its dissemination, academic occupations focusing on dissemination have been devalued. Within this environment librarians have been passive disseminators of information, rather than 'pursu[ing] an active, intellectual role in providing access to the contents of material' (Carpenter 1996, 87-8).

Faced with a new multiplicity of sources in the twenty-first century, librarians might consider how they responded to the information environment of one hundred years ago. Perhaps it is time to become tool-builders again: to develop the technical expertise to add value to information for researchers and create knowledge as well as to facilitate access to it. As Jerry Campbell wrote at the beginning of the Internet era: 'Increasingly, librarians need deep technical proficiency. Without it, we are a step removed from being able to conceptualize, design, and re-engineer the information and knowledge delivery systems of the near future' (Campbell 1993, 562). In this environment, can law librarians become the new Blackstones Bob Berring calls upon to use their knowledge and toolbuilding skills to re-conceptualize the structure of legal information now as William Blackstone did for the common law in the eighteenth century, and as John B. West and his associates did for American lawyers facing the multiplicity of sources of the late 1800s? (Berring 2000, 315, 317-8).

As noted earlier, Betty Haugen has identified three major characteristics of legal information in the early twenty-first century: increased inequality of access, increased private control over the distribution of intellectual content, and prohibitive costs of

\footnotetext{
${ }^{21}$ See list in Garavaglia 2011, 345-353.

${ }^{22}$ See Garavaglia (2011); AALL Research Agenda (2000), http://www.aallnet.org/committee/research/ agenda.asp, accessed 20 July 2010.

${ }^{23}$ For a less optimistic view, see Berring (2011).
} 
maintaining access to legal information even for law libraries in affluent parts of the world (Haugen 2005, 473). To influence the resolution of these global issues, law librarians with international concerns must think harder about what they can do to facilitate free and open access to legal information.

The mission statements of both the IALL and the Law Libraries Section of IFLA proclaim support for free and open access to legal information. IALL 'promotes free access to legal information on a worldwide basis through policy statements and scholarship, 24; the IFLA section 'recogniz[es] that equitable and permanent public access to authentic legal information is a necessary requirement for a just and democratic society worldwide'. ${ }^{25}$ To accomplish these goals, law librarians world-wide need to become more knowledgeable about the Free Access to Law Movement and other efforts to improve access to the law, and to be more active participants in efforts to assist those outside the legal profession to make use of the growing amounts of legal information available electronically. ${ }^{26}$ There are at least three areas in which law librarians can make significant contributions to these efforts: improving access to legal scholarship and commentary about the law; leading the way in ensuring that legal information published in digital formats is authenticated and preserved; and working with others to provide guidance to non-professional users of online legal information.

\section{Improving access to scholarship and commentary}

It is understandable, given the nature of their mission and commitment, that the legal information institutes and others involved in the Free Access to Law Movement have so far provided only limited access to legal scholarship and other forms of commentary on the law (Danner 2008, 362-3). Yet, as Michael Carroll has written, if '[a]ccess to law matters . . . access to legal scholarship matters too' (Carroll 2006, 743). What also matters is how the two literatures are linked together and how web tools can be used to develop and better connect commentary on the law to the texts of the law. Surely there is a role here for librarians in service to the broader communities created though open access to law and legal scholarship. John Willinsky's Access Principle promotes the idea that open access to scholarship is not merely a good thing to do, but an obligation. For Willinsky, the transformation from print to online means that not only researchers and scholars, but also 'scholarly societies, publishers, and research libraries have now to ask themselves whether ... they are using this new technology to do as much as they can to advance and improve access to research and scholarship' and recognizing that a 'commitment to the value and quality of scholarly research carries with it a responsibility to extend the circulation of such work as far as possible and ideally to all who are in interested in it and all who might profit by it' (Willinsky 2006, vii). This is an obligation that includes all participants in the scholarly communications system, particularly librarians. ${ }^{27}$

\footnotetext{
${ }^{24}$ http://iall.org/about.html, accessed 9 August 2010.

${ }^{25} \mathrm{http}: / / \mathrm{www}$.ifla.org/en/about-the-law-libraries-section, accessed 9 August 2010.

${ }^{26}$ See Greenleaf (2011). The World Legal Information Institute (WorldLII) website provides access to the resources made available by the LIIs, as well as background on the free Access to Law Movement, http://www.worldlii.org/, accessed 17 August 2010. ${ }^{27}$ Obvious means for librarians to promote open access to legal scholarship include collaborating to
establish institutional repositories of their faculty’s scholarship (see for instance the Nellco Legal
} 


\section{Preservation and authentication of legal information}

Law librarians can also bring to the open access movement their special concerns with preservation of digitally-published legal materials. In the long term, open access to legal materials must encompass more than merely providing access to documents: because they can be easily manipulated in electronic formats, legal texts must be authenticated; they must be preserved in electronic formats; and they must be both easily and permanently accessible. ${ }^{28}$ Yet, authentication and preservation are not likely to be primary concerns either for lawyers or for public users of legal information. ${ }^{29}$

One question is whether, in their own rush to make digital texts available, librarians themselves will remember the importance of authentication and proper preservation of authoritative legal information. But, if not law librarians, then who? A positive development in the USA has been the support and involvement of law librarians in the Law.Gov project, an effort to ensure that governmental institutions make the primary legal materials of the United States readily available to all as distributed, authenticated, well-formatted data. ${ }^{30}$ John Palfrey has posited a similar goal for other countries (Palfrey 2010, 181-182).

\section{Access to legal guidance and justice}

In his book: The End of Lawyers?, Richard Susskind argues that 'access to justice is as much about dispute avoidance as it is about dispute resolution' and that 'readier, cheaper, and more widespread access to legal guidance should give rise to a more just society in the same way that immunization leads to a healthier community' (Susskind 2008, 231; emphasis in original). A major factor in improving access to justice (a 'building block' in Susskind's parlance), should be improved access to the law via the Internet. Making the Law Work for Everyone, a 2008 report of the United Nations Commission on Legal Empowerment of the Poor, applies the idea specifically to poorer nations, groups, and individuals:

Empowering the poor through improved dissemination of legal information and formation of peer groups (self-help) are first-step strategies towards justice. ....Modern information and communication technologies are particularly well suited to support interventions geared towards strengthening information-sharing groups, teaching the poor about their rights, and encouraging non-formal legal education (I Making the Law Work 2008, 64).

\footnotetext{
Scholarship Repository, http://lsr.nellco.org/, accessed 18 August 2010) and working to encourage freely accessible web publication of law journals (see Durham Statement on Open Access to Legal Scholarship, http://cyber.law.harvard.edu/publications/durhamstatement, accessed 18 August 2010). See also Danner, Leong and Miller (2011).

${ }^{28}$ Specific issues and concerns for preservation of legal materials have been well articulated in a report of the Legal Information Preservation Alliance (Cobb and Allen-Hart 2005).

${ }^{29}$ As put by Jason Wilson in an aptly named blog posting: 'I don't know that many lawyers who have given the problem of authentication much thought. In most conversations about case law access, the issues I have discussed are scope of coverage and whether the site's UI and search tools are both easy to use and robust enough to keep you from wasting too much time looking for authority' (Wilson 2009).

${ }^{30}$ Law.Gov: A Proposed Distributed Repository of All Primary Legal Materials of the United States, http://resource.org/law.gov/index.html, accessed 12 August 2010.
} 
Writing at the end of the twentieth century, Bob Berring envisioned a complex legal information environment where 'researchers will yearn for guidance and the reliability of individual expertise. More personal, more interactive, and more specialized, such information systems can hold things together' (Berring 2000, 315). As more and more legal materials become available for free on the web, law librarians will need to engage in meaningful collaboration with others who are committed to making the law not only available, but meaningfully accessible and understandable. To make their open access initiatives truly valuable, to provide this guidance, librarians will need 'to write more code... and [to] dig deeper into the culture of information access that our users are increasingly a part of - for good and for ill' (Palfrey 2010,187). Richard Susskind's vision for improving access to justice and law through accessible legal information systems calls for more than increased free postings of legal texts by government agencies or the LIIs. ${ }^{31}$ For the United Kingdom, he looks forward to 'a Wikipedia-like service' that:

would evolve a corpus of UK law like no other: a resource readily available to lawyers and lay people; a free web of inter-linked materials; packed with scholarly analysis and commentary, supplemented by useful guidance and procedure; rendered intensely practical by the addition of action points and standard documents; and underpinned by direct access to legislation and case law.... (Susskind 2008, 260).

For Susskind, accessible legal information systems will be in place only 'when citizens can go online and ... secure digestible and actionable guidance that helps them in their own precise circumstances' (Susskind 2008, 261). Philip Leith uses a biblical analogy to place citizen access to the law within the broader movement for e-government:

The central notion is that there is - like the Protestant and God's word in the Bible - a direct link between the citizen and the law, without the requirement for a priestly intermediary to explain either the Bible or planning/property legislation. This is the ideal for eGov - the citizen enabled to understand the law of his or her land (Leith 2010).

Who will put these systems together? Leith says that re-engineering access to the law 'must mean the coming together of lawyers and these technologists to describe and test tools which might make citizen access to law better' (Leith 2010). To Susskind: 'This online resource could be established and maintained collectively by the legal profession; by practitioners, judges, academics, and voluntary workers' (Susskind 2008, 260). In the USA, Ian Gallacher has called upon American law schools to create a comprehensive open access archive of US law (Gallacher 2008). Is there not room in these visions for the skills of law librarians committed to working in collaboration with others using open access tools to expand access to justice for everyone?

At the 2009 Law via the Internet Conference Olivier Charbonneau, a librarian and doctoral candidate in law at Concordia University in Montreal, presented a paper inspired by the UN report: Making the Law Work for Everyone. In his paper: 'Collaboration and

\footnotetext{
${ }^{31}$ As Philip Leith and Karen McCullagh said at a BILETA conference in 2003: 'It is well known that law is difficult to access - even systems such as BAILII, which are free and available, do not really enable 'understanding' of the law since they do not apply any coherent conceptual overview onto the materials. That, of course, is not their aim...' (Leith and McCullagh 2003).
} 
Open Access to Law: How Can Web 2.0 Technologies Help Us Understand the Law?', Charbonneau develops an intriguing model to describe the interactions between legal information users and content (or, as he terms them, 'agents and documents'). He proposes applying web 2.0 applications to facilitate collaboration and sharing of information about legal texts by creating links between primary sources and formal or informal commentary on the texts or point of law under study.

And there are efforts underway to build such systems. In the USA, the Cornell Legal Information Institute's WEX is a collaboratively-edited legal dictionary and encyclopaedia, intended for broad use by 'practically everyone, even law students and lawyers entering new areas of law. ${ }^{32}$ Spindle Law, another US initiative, aims to guide lawyers (and presumably others using the site) 'to the legal information they need and [help] them write their legal documents as they research. It supports the creation of reliable content by designated experts and other Spindle users, activating a dynamic online legal community and opening a new kind of discussion about the law. ${ }^{, 33}$ JurisPedia: the Shared $\mathrm{Law}^{34}$ is a wiki-based encyclopaedia of 'worldwide law, legal and political sciences' in multiple languages with the stated 'modest' ambition 'to offer simple information on countries law systems and particularly on those least represented on the legal Internet'. Staffan Malmgren has described his project to create a site providing free commentary on Swedish statutory law, ${ }^{35}$ using collaborative writing tools and law student volunteers (Malmgren 2010).

I noted earlier John Palfrey's statement that 'Libraries must [now] perceive our primary function as serving communities rather than building collections' (Palfrey 2010, 185). The open access repositories and journals created at law schools and universities expose legal scholarship to broader, indeed to world-wide, audiences, both within and outside the academy. Of course, law school scholarship repositories and open access law journals add to the 'multiplicity of sources' with which legal researchers and others must deal, but coupled with thoughtful application of new communications technologies they may also provide an opportunity for librarians to facilitate the creation of new knowledge of value to others beyond their local constituencies. Open access expands the communities served by individual law schools and universities not only to other academic institutions, but to anyone seeking knowledge about the law.

By definition, open access initiatives expand the communities served by libraries, creating opportunities not only for new services, but for librarians to develop and use new tools to enable not only the dissemination but the creation of new knowledge. There is no reason for librarians not to embrace efforts to link primary sources of law to expert and public commentary about the law. This is a time in which users of legal information are faced with a new 'multiplicity of sources', a problem that is unlikely to be tamed by focusing on development of local collections, but by serving communities broadly defined.

\footnotetext{
${ }^{32}$ http://topics.law.cornell.edu/wex/FAQ, accessed 8 August 2010. For a comparative perspective, see Barendrecht (2010).

${ }^{33} \mathrm{http}: / /$ spindlelaw.com/about, accessed 8 August 2010.

${ }^{34}$ http://en.jurispedia.org/index.php/Main_Page, accessed 18 August 2010.

${ }^{35}$ See lagen.nu, https://lagen.nu/, accessed 18 August 2010.
} 


\section{Conclusion: Defining International Law Librarianship}

A definition of international law librarianship can only be constructed on the basis of the commonalities shared by law librarians throughout the world. In the early twentyfirst century, all law librarians face an information environment that is moving rapidly from print toward an all-electronic future: a future characterized by a new multiplicity of sources for legal research which will provide excitement and challenges, not only in the new formats in which legal information is accessed and retained, but in the changed roles that libraries and librarians will play working with those who use that information professionally, for scholarship, or in their daily lives.

As they face these challenges, law librarians can call upon a vibrant shared professional literature which developed over 25 years as librarians and others grappled with the impacts of electronic publishing and the Internet on the relatively stable and predictable print-based legal research environment of the twentieth century. In the twenty-first century law librarians with global interests can readily share and develop their professional knowledge and expertise in ways not possible before.

Although in many countries the print environment failed to provide equitable means of access to the law for those unable to pay the costs for commercial publications or without access to public law libraries, it did allow law librarians to develop and preserve collections and provide help for those who made use of their services. Now, one area in which the knowledge and skills of international law librarians will be most needed and best applied is in providing ready and meaningful access to law for both legal professionals and citizens alike. In the legal information environment of the twenty-first century, the communities served by law libraries and law librarians have expanded to encompass all those with needs for accurate legal information and the ability to understand how it affects them. Here perhaps is where we will find the future of international law librarianship. 


\section{References}

AALL Biennial Salary Survey \& Organizational Characteristics 2009 (Chicago: American Association of Law Libraries).

Bacon, R. (c. 1616), 'A Proposition to His Majesty ... Touching the Compiling, and Amendment of the Law' in Spedding, J. et al. eds (1861-1869), The Works of Francis Bacon, vol. 13 (London: Longman).

Barendrecht, M. (2010), 'Legal Aid, Accessible Courts or Legal Information? Three Access to Justice Strategies Compared', Tilburg University Legal Studies Working Paper No. 24/2010, http://ssrn.com/abstract=1706825, accessed 8 March 2011.

Barkan, S., Mersky, R. and Dunn, D. (2009), Fundamentals of Legal Research 9th edn. (New York: Thomson Reuters/Foundation).

Berring, R. (2011), 'The End of Scholarly Bibliography: Reconceptualizing Law Librarianship', (forthcoming Law Library Journal), http://ssrn.com/abstract=1929017.

Berring, R. (2000a), 'Legal Research and the World of Thinkable Thoughts', Journal of Appellate Practice and Process 2:2, 305-18.

Berring, R. (2000b), 'Legal Information and the Search for Cognitive Authority', California Law Review 88:6, 1673-1708.

Bing, J. (ed.) (1984), Handbook of Legal Information Retrieval (Elsevier: Amsterdam).

Bing, J. (2003), 'The Policies of Legal Information Services: a Perspective of Three Decades', in Mirfield, P. and Smith, R., Essays for Colin Tapper (LexisNexis: London).

Bing, J., (2010), 'Let There be LITE: A Brief History of Legal Information Retrieval, European Journal of Law and Technology, 1:1, http://ejlt.org//article/view/15, accessed 20 August 2010.

Bing J. and Harvold T. (1977) Legal Decisions and Information Systems (Oslo: Universitets Forlaget).

Boon, A. and Webb, J. (2010), 'The Legal Professions as Stakeholders in the Academy in England and Wales', in Cownie, F. (ed.) Stakeholders in the Law School (Hart: Oxford and Portland).

Campbell, J. (1993), 'Choosing to Have a Future', American Libraries 24:6, 560-4.

Carpenter, K. (1996), 'A Library Historian Looks at Librarianship', Daedalus, 96:1, 77 102.

Carroll, M. (2006), 'The Movement for Open Access Law', Lewis and Clark Law Review, 10:4, 741-60.

Carr, N. (2010), The Shallows: What the Internet is Doing to Our Brains (New York: Norton).

Cobb, J. and Allen-Hart, J. (2005), Preserving Legal Materials in Digital Formats. (Legal Information Preservation Alliance), http://www.aallnet.org/committee/ lipa/LIPA_White_Paper_Final.pdf, accessed 12 August 2010.

Cohen, M. (1969), 'Research Habits of Lawyers', Jurimetrics Journal, 9:4, 183-94.

Cohen, M. (1998; supp. 2003), A Bibliography of Early American Law (Buffalo, N.Y.: Hein).

Cohen, M. (2003) 'An Historical Overview of American Legal Publishing', International Journal of Legal Information 31:2, 168-78.

Christiansen, L., Stombler, M. and Thaxton, L. (2004), 'A Report on Librarian-Faculty Relations from a Sociological Perspective,' Journal of Academic Librarianship 30:2, 116-21. 
Danner, R. (2003), 'Contemporary and Future Directions in American Legal Research: Responding to the Threat of the Available', International Journal of Legal Information 31:2, 179-204.

Danner, R. (2007), 'Applying the Access Principle in Law: The Responsibilities of the Legal Scholar', International Journal of Legal Information 35:3, 355-95.

Danner, R. (2008), 'Legal Information and the Development of American Law: Writings on the Form and Structure of the Published Law', in Danner, R. and Houdek, F. (2008).

Danner, R., Leong, K. and Miller, W. (2011), 'The Durham Statement Two Years Later: Open Access in the Law School Journal Environment,' Law Library Journal 103: 1, 39-54.

Danner, R. and Houdek, F. (eds.) (2008), Legal Information and the Development of American Law (St. Paul, Minn.:Thomson/West).

Danner, R. and Winterton, J. (eds.) (2011), IALL International Handbook of Legal Information Management (Farnham, England: Ashgate).

Danner R., Estes, M. and Meadows, J. (2009), 'Law Librarianship', in Encyclopedia of Library and Information Sciences 3rd edn, 1:1, 3212-34.

Davidson, S. (2010), 'Way Beyond Legal Research: Understanding the Research Habits of Legal Scholars', Law Library Journal, 102:4, 561-579.

Davis, J. (1918), 'The Case for the Case Lawyer', Massachusetts Law Quarterly 3:3, 99110.

Donovan, J. (2008), 'Skating on Thin Intermediation: Can Libraries Survive?', Legal Reference Services Quarterly, 27:2/3, 95-116.

Evans J. (2008), 'Electronic Publication and the Narrowing of Science and Scholarship', Science, 321: 5887, 395-99.

Gallacher, I. (2008), “Aux Armes, Citoyens!:” Time for Law Schools to Lead the Movement for Free and Open Access to the Law', University of Toledo Law Review 40:1, 1-52.

Garavaglia, B. (2011), “A Research Agenda for International Law Librarianship" in Danner, R. and Winterton, J. (2011).

Greenleaf, G. (2004), Jon Bing and the History of Computerised Legal Research - Some Missing Links in Torvund, O. and Bygrave, L. (eds) Et tilbakeblikk på fremtiden (Looking back at the future) 61-75 (Oslo: Unipub).

Greenleaf, G. (2010), 'The Global Development of Free Access to Legal Information' in Paliwala, A. (ed.) A History of Legal Informatics (Zaragoza: University of Zaragoza Press).

Greenleaf, G. (2011), 'Free Access to Legal Information, LIIs, and the Free Access to Law Movement' in Danner, R. and Winterton, J. (2011).

Haugen, B. (2005), 'The Impact of Globalisation on Law Libraries', International Journal of Legal Information 33:3, 471-78.

Hicks, F. (1923) Materials and Methods of Legal Research with Bibliographic Manual (Rochester, N.Y.: Lawyers Co-operative).

Hoeflich, M. (2002), 'The Lawyer as Pragmatic Reader: The History of Legal CommonPlacing', Arkansas Law Review 55:1, 87-122.

Housewright, R. and Schonfeld, R. (2008), Ithaka's 2006 Studies of Key Stakeholders in the Digital Transformation in Higher Education at http://www.ithaka.org/ithaka-s$\mathrm{r} /$ research/Ithakas\%202006\%20Studies\%20of\%20Key\%20Stakeholders\%20in\%20the $\% 20$ Digital\%20Transformation\%20in\%20Higher\%20Education.pdf, accessed 18 
August 2010.

Jacobstein, J. and Mersky, R. (1977), Fundamentals of Legal Research (Mineola, N.Y.: Foundation).

Joint, N. (2006) 'Digital Libraries and the Future of the Library Profession,' Library Review 56:1, 12-23.

Katsh, M. (1984), 'Communications Revolutions and Legal Revolutions: The New Media and the Future of Law', Nova Law Journal 8:3, 631-70.

Katz, R. (2010), 'Scholars, Scholarship, and the Scholarly Enterprise in the Digital Age', Educause Review, 45: 2, 44-56.

Katz, S. (2010), 'The Law Librarian's Role in the Scholarly Enterprise Colloquium,' Journal of Law \& Education 39:3, 355-64.

Kellogg, R. (1987) 'Faculty Members and Academic Librarians: Distinctive Differences', College \& Research Libraries News 48:10, 602-06.

Kent, J. (1826-1830), Commentaries on American Law (New York: O. Halstead).

Knudsen, H. (2011), "Collection building: Foreign, Comparative and International Law in Print," in in Danner, R. and Winterton, J. (2011).

Kotter, W. (1999), 'Bridging the Great Divide: Improving Relations between Librarians and Classroom Faculty', Journal of Academic Librarianship 25:4, 294-303.

Lamont, M. (2009), How Professors Think: Inside the Curious World of Academic Judgment (Cambridge, Mass.: Harvard).

Lankes, R. (11 July 2010), Keynote Address, 103d Annual Meeting of the American Association of Law Libraries, at http://www.softconference.com/aall/sessionDetail. asp?SID=208430, accessed 21 July 2010.

Leith P. (2010), 'Re-engineering Sources of Law for Unaided Litigants', European Journal of Law and Technology 1:1, http://ejlt.org//article/view/20/36, accessed 19 August 2010.

Leith, P. and McCullagh, K. (2003), 'Developing European Legal Information Markets based on Government Information: First Findings from the Add-Wijzer Project', 18th BILETA Conference: Controlling Information in the Online Environment, April, 2003, QMW, London, http://www.bileta.ac.uk/Document\%20Library/1/Developing $\%$ 20European\%20Legal\%20Information\%20Markets\%20Based\%20on\%20Governme nt $\% 20$ Information $\% 20-\% 20$ First $\% 20$ Findings $\% 20$ from $\% 20$ The $\% 20$ Add-

Wijzer\%20Project.pdf, accessed 19 August 2010.

Lewis, S. (2002), 'A Three-Tiered Approach to Faculty Services Librarianship in the Law School Environment', Law Library Journal 94:1, 89-100.

Llewellyn, K. (1931), 'Legal Tradition and Social Science Method - A Realist's Critique, in Essays on Research in the Social Sciences (Washington, Brookings Institution).

Making the Law Work for Everyone (2008) (New York: United Nations Commission on Legal Empowerment of the Poor).

Malmgren, S. (2010), 'Crowdsourcing Legal Commentary', VoxPopulii, http://blog. law.cornell.edu/voxpop/2010/03/31/crowdsourcing-legal-commentary/, accessed 18 August 2010.

'The New "Reporters"' (1885), American Law Review 19:6, 930-32.

Nycum, P. (1975), 'Legal Research - The Unrecognized Legal Discipline', in May R. (ed.), Sense \& Systems in Automated Law Research, (Chicago: American Bar Association), 81- 108.

Palfrey, J. (2010) 'Cornerstones of Law Libraries for an Era of Digital-Plus', Law Library Journal 102:2, 171-90. 
Paliwala, A. (ed.) (2010), A History of Legal Informatics (Zaragoza: Prensas Universitarias de Zaragoza).

Pierce, S. (1992), 'Dead Germans and the Theory of Librarianship', American Libraries 23:8, 641-43.

Ranganathan, S. (1931), The Five Laws of Library Science (Madras: Madras Library Association; London: E. Goldston).

'Review of Peters's Digest of Cases' (1840), American Jurist 23:45, 243-45.

Ross, L. and Sennyey, P. (2008), 'The Library is Dead, Long Live the Library! The Practice of Academic Librarianship and the Digital Revolution', Journal of Academic Librarianship 34: 2, 45-152.

Schauer, F. and Wise, V. (2000), 'NonLegal Information and the Delegalization of Law', Journal of Legal Studies 29:1, 495-515.

Shaw, J. (2010), 'Gutenberg 2.0: Harvard's Libraries Deal with Disruptive Change', Harvard Magazine May-June 2010, 36-41; 82-3.

Schilt, M. (2007), "Faculty Services in the 21st Century: Evolution and Innovation," Legal Reference Services Quarterly, 26: 1/2), 187-207.

Schonfeld, R. and Housewright, R. (2010), Faculty Survey 2009: Key Strategic Insights for Libraries, Publishers, and Societies, at http://www.ithaka.org/ithaka-sr/research/faculty-surveys-2000-2009/Faculty\%20Study\%202009.pdf. accessed 18 August 2010.

Shera, J. (1968), 'Of Librarianship, Documentation and Information Science', Unesco Bulletin for Libraries 22:2, 58-65.

Story, J. (1829), 'An Address Delivered before the Members of the Suffolk Bar, at their Anniversary, on the Fourth of September, 1821, at Boston', American Jurist 1:1, 31.

Susskind, R. (2008), The End of Lawyers?: Rethinking the Nature of Legal Services (Oxford: Oxford University Press).

Sutton, S. (1995), 'Core Competencies for the Information Professions and the Evolution of Skill Sets' Education Libraries 18:3, 6-11.

T.G. (1992), 'Some of These "Dead Germans" are Neither Dead nor Germans', American Libraries 23:8, 643.

'Toward a Renaissance in Law Librarianship: Report of the Special Committee on the Renaissance of Law Librarianship in the Information Age,' in Danner, R. (ed.) (1997) Toward a Renaissance in Law Librarianship (Chicago: American Association of Law Libraries).

Treitel, G. (2003), 'Foreword', in Mirfield, P. and Smith, R., Essays for Colin Tapper (LexisNexis: London).

Wilson, J. (2009), 'Screw Authenticity. I Just Want it for Free', rethinc.k: Thoughts on the Business of Legal Publishing, http://www.jasnwilsn.com/2009/07/10/screwauthenticity-i-just-want-it-for-free/, accessed 18 August 2010.

Windsor, E. and Friedman, R. (2010) 'Law Libraries Transformed,' LLRX, at http://www.llrx.com/features/lawlibrariestransformed.htm, accessed 18 August 2010.

Wahlgren, P. (1999), The Quest for Law: Law Libraries and Legal Information Management of the Future (Jure AB: Stockholm).

Willinsky, J. (2006), The Access Principle: The Case for Open Access to Research and Scholarship (Cambridge, Mass.: MIT).

Wolfe, Gary (1994), 'The (Second Phase of the) Revolution Has Begun: Don't look now, but Prodigy, AOL, and CompuServe are all suddenly obsolete - and Mosaic is well on its way to becoming the world's standard interface', Wired Magazine 2:10, 116-21, 
150-4. http://www.wired.com/wired/archive/2.10/mosaic.html, accessed 4 July 2010. Worley, L. (ed.) (2006), BIALL Handbook of Legal Information Management (Aldershot: Ashgate). 